\title{
Peniel E. Joseph: the Sword and the Shield: the Revolutionary Lives of Malcolm X and Martin Luther King, Jr.
}

\author{
New York: Basic Books, 2020. x + 373 pp. ISBN 978-1-5416-5 Hardback
}

\author{
Floyd W. Hayes III ${ }^{1}$
}

Published online: 7 August 2020

C) The Author(s) 2020

In the 1950s and 1960s, the Honorable El-Hajj Malik El-Shabazz (aka Malcolm X) and the Reverend Martin Luther King, Jr. strode across the landscape of this place called America, leading their Black followers in the monumental struggle for freedom, justice, equality, citizenship, and democracy. From America's founding as a colonial and slave society, Black people were excluded from participation in virtually every aspect of the social order. Indeed, the US Constitution defined the great multitude of Africandescended Americans as a class of sub-humanity. Therefore, the main objective of white Americans has been to stifle Black development-identity, social, economic, cultural, and political - at all costs. Of course, White people historically have denied this reality, producing this nation's culture of pretense. America lies to itself. This nation may have been theoretically conceived in liberty, but slavery and racism damned it as a democracy. No matter what theoretical approach to the study of democracy-normative, realist, empirical, behavioral, representative, deliberative, power, etc.-America is not, and never has been, a democracy. Hence, it could be argued that Malcolm X and King led struggles that were in vain. How could that be possible? What is necessary is a critical reevaluation of democratic politics, which this essay will undertake briefly near its end.

Now comes The Sword and The Shield: The Revolutionary Lives of Malcolm X and Martin Luther King, Jr. by historian Peniel E. Joseph, 29 years after Black liberation theology founder James H. Cone published Martin \& Malcolm \& America: A Dream or a Nightmare (Cone 1991), when Cone's book was published, the Civil Rights and Black Power Movements had been crushed by the power of the brutal American political state. Cone sought to resurrect the memories, ideas, and activities of the two major leaders of the struggle for Black freedom during the mid-twentieth century. Cone informs that he gained his perspectives on Christian religion from liberal moralist King and his Black consciousness from Malcolm X's radical realism. While King embraced hope, the American dream, and

Floyd W. Hayes, III

floyd.hayes3@gmail.com

1 Center for Africana Studies, Johns Hopkins University, Baltimore, MD 21218, USA 
belief in the goodness of white people and America, Malcolm X believed that the struggle for Black liberation entailed a struggle against America's white power structure. He distrusted White people and rejected the concept of the American dream. Cone argued, however, that as their lives came to an end, Malcolm's and Martin's ideas and activities tended to converge. Significantly, Peniel Joseph puts forward a similar thesis.

Joseph follows the lives of Malcolm X and King, from their early years as religious figures - Malcolm X as a Muslim minister and King as a Christian minister - to their deaths by assassination. Joseph views each man as a revolutionary leader. As a young Muslim minister, Malcolm X modernized the Nation of Islam, building it into a highly organized and nationally recognized Black religious and economic formation that recruited thousands of working class and underclass Black people throughout urban America. Malcolm X sought black identity, pride, integrity, unity, power, and self-defense. Malcolm X soundly, and often, criticized King's belief in the American dream, calling it a nightmare; he decried King's trust in White people, especially since they would so often betray him; and he raged against King's theory and practice of nonviolence, reasoning that since the US government refused to protect Black people, they had a right to protect themselves. One wonders if Malcolm X did not also view King as a "house Negro," because King so often met with powerful Whites, such as presidents Richard Nixon, John Kennedy, Lyndon B. Johnson, along with Bobby Kennedy. If Black people were struggling for civil rights, they were not yet citizens, but rather victims, of a failed democracy. If America was truly a democracy, Black people would not have to fight for citizenship. As a radical realist, Malcolm X viewed the struggle for Black freedom as a struggle for power-Black power! He constantly indicted America, arguing that White people had denied Black people their civil rights, but more importantly, their human rights since this nation's birth. Hence, this place called America was not a democracy.

Martin Luther King, Jr. was the most well-known and recognized civil rights leader in this place called America. He maintained a passionate faith in the American project, a belief in the American dream, and a trust in White people. As the leader of the Civil Rights Movement, King was committed to the practice of civil disobedient nonviolent marching and kneeling in order to achieve racial integration. It was this approach that King learned from studying the Indian anticolonial leader Mahatma Gandhi. It needs to be said, however, that nonviolence for Gandhi was a strategic approach, not a way of life as it was for King. Indeed, in his essay, entitled "The Doctrine of the Sword," Gandhi stated:

I do believe that where there is only a choice between cowardice and violence I would advise violence. Thus when my eldest son asked me what he should have done, had he been present when I was almost fatally assaulted in 1908, whether he should have run away and seen me killed or whether he should have used his physical force which he could and wanted to use, and defended me, I told him that it was his duty to defend me even by using violence. Hence it was that I took part in the Boer War, the so-called Zulu rebellion and the late war. Hence also do I advocate training in arms for those who believe in the method of violence. I would rather have India resort to arms in order to defend her honor than that she should in a cowardly manner become or remain a helpless witness to her own dishonor (Gandhi 1920).

Why did King selectively read Gandhi? Gandhi was an apostle of nonviolence, but he also knew how to engage in violence when circumstances required. Unfortunately, King pursued 
nonviolence as a way of life. Why? It might have strengthened Joseph's assessment of King by noting King's partial and insufficient reading of Gandhi regarding the use of force in political struggle. King was the darling of White American liberals, as they considered him to be very much like themselves. This was especially true as Malcolm X became increasingly prominent among and respected by growing multitudes of Black and other people of color in America and globally. As it stands, many of King's followers were seriously injured by White attackers while following him. I am persuaded that had King advocated strategic armed resistance, the struggle for Black liberation and citizenship would have been more effective and longer-lasting. Here, I have in mind the organized resistance represented by those secret groups examined in, but not limited to, the following books: The Deacons for Defense: Armed Resistance and the Civil Rights Movement by Lance Hill (Hill 2004); Radio Free Dixie: Robert Williams \& the Roots of Black Power by Timothy B. Tyson (Tyson 1999); and We Will Shoot Back: Armed Resistance in the Mississippi Freedom Movement by Akinyele Omowale Umoja (Umoja 2013). Racist white southerners feared to engage these groups in violent confrontations. Yet, King remained determined in his commitment to the practice of nonviolent and unarmed political protest.

However, as popular opinion grew against America's imperialistic and disastrous intervention in the Vietnam War, King realized that remaining silent about the war was a contradiction to his nonviolent principles. He was forced to think more globally; he could not reject violence in the Civil Rights Movement, yet acquiesce to it in Vietnam. In the context of declining white liberalism and the intensification of America's invasion of Southeast Asia, King publicly opposed the war, bringing upon himself, and even the Civil Rights Movement, mounting white antagonism. He also became the target of some Black criticism. In addition, King realized more and more that the movement needed to shift focus to a serious concern about urban poverty. It was becoming increasingly clear to him that, as a result of racism and capitalism, the Black situation was under increasing assault. President Johnson's Great Society did not prove beneficial to the great multitude of America's urban poor people. Therefore, in 1967, King began planning a Poor People's Campaign. As Joseph argues, King made a radical transition to a revolutionary, whose goal was to terminate racism, poverty, and war.

Joseph asserts that by the time each of them was assassinated, Malcolm X and Martin began to agree increasingly regarding their ideologies and political practice. It is almost as if he is saying that to examine Martin, it is necessary to study Malcolm X and vice versa. Joseph maintains that King began to shift closer to Malcolm X's position and that Malcolm $\mathrm{X}$ began to embrace Martin's views. For me, this "convergence thesis" presents problems. Certainly, King's growing awareness of and concern for the effects of racism and poverty on Black Americans came close to Malcolm X's critique of racism and capitalism. Yet, nothing about King's rhetoric or political practice demonstrated any agreement with Malcolm X's call for Black self-defense strategies. Second, Malcolm X continued to distrust white Americans, even though his voyage to Mecca and Africa allowed him to witness white Muslims. On his return to this place called America, Malcolm X expressed a willingness to work with some whites, but they could not lead Black organizations.

Significantly, Malcolm X continued to be critical of America as a democratic social order up to the time that he was assassinated by members of the Newark, New Jersey, Muslim Mosque. On the other hand, Reverend Martin Luther King, Jr. ended his life with an ongoing faith and hope in what he considered to be American democracy. Their differences could not be more apparent; America was not then, nor has it ever been, a democracy. The 
notion of America as a democracy is a veil of illusion. As I noted earlier, the existence of chattel slavery condemned any claim of American democracy. Colonial Europeans, who called themselves white, as well as the US Constitution, proclaimed and practiced the exclusion of slaves and their descendants from the benefits of democracy and its so-called American dream. Slave-owning classes imposed a violent and savage dehumanization process that created a White supremacist political formation, defined slaves as a class of sub-humanity, broke up traditional African families and communities, denied chattel slaves and their descendants quality education, commodified slaves and their descendants, rendering them an economically dependent people, and denied slaves all political rights, including the right to freedom of speech, free assembly, and human rights. Slaves were not allowed to vote, organize, and protest. Significantly, the process of enslavement was buttressed by strict and brutal discipline. Even poor Whites enjoyed limited political and economic freedoms. Indeed, remnants of these historical dynamics have been carried well into the contemporary moment. Although Joseph seems to accept that America has been a democracy, it is important to challenge this conventional yet flawed notion. To even suggest that America was, or has become, a democracy is inaccurate; it is a veil of illusion.

While Joseph's study is well researched and written, it is in dealing with the contradiction of democracy in a violently oppressive slave society that he could have made a monumental contribution to the long tradition of Black scholarship. What is needed now more than ever is a Scholarship of Indictment that challenges, corrects, and goes beyond the interpretations and analyses of conventional White scholarship. New ideas, concepts, theories, and arguments are needed. The most fundamental project should be rethinking American origins and development-how slave trading, chattel slavery, racism, sexism, and capitalism precluded the emergence and practice of an authentic and multicultural/multiracial democracy.

Open Access This article is licensed under a Creative Commons Attribution 4.0 International License, which permits use, sharing, adaptation, distribution and reproduction in any medium or format, as long as you give appropriate credit to the original author(s) and the source, provide a link to the Creative Commons licence, and indicate if changes were made. The images or other third party material in this article are included in the article's Creative Commons licence, unless indicated otherwise in a credit line to the material. If material is not included in the article's Creative Commons licence and your intended use is not permitted by statutory regulation or exceeds the permitted use, you will need to obtain permission directly from the copyright holder. To view a copy of this licence, visit http://creativecommons.org/licenses/by/4.0/.

\section{References}

Cone, J. (1991). Martin \& Malcolm \& America: A Dream or a Nightmare. Maryknoll: Orbis Books.

Gandhi, M. K. (1920). http://www.mkgandhi.org/nonviolence/D_sword.htm.

Hill, L. (2004). The deacons for defense: armed resistance and the civil rights movement. Chapel Hill: University of North Carolina Press.

Tyson, T. B. (1999). Radio Free Dixie: Robert Williams \& the roots of Black power. Chapel Hill: University of North Carolina Press.

Umoja, A. O. (2013). We will shoot back: armed resistance in the Mississippi Freedom Movement. New York: New York University Press.

Publisher's Note Springer Nature remains neutral with regard to jurisdictional claims in published maps and institutional affiliations. 